\title{
PENERAPAN MODEL PEMBELAJARAN KOOPERATIF TIPE GROUP INVESTIGATION UNTUK MENINGKATKAN HASIL BELAJAR IPA KELAS V SD NEGERI 104231 SUGIHARJO BATANGKUIS
}

\author{
Demmu Karo-Karo \\ Surel: demmu_karokaro@yahoo.com
}

\begin{abstract}
ABSTRAK
Penelitian ini merupakan penelitian tindakan kelas yang dilaksanakan dalam dua siklus. Subjek pada penelitian ini adalah siswa kelas V SDN No.104231 Sugiharjo, Batang Kuis T.A 2014/2015 yang berjumlah 36 siswa terdiri dari 20 orang siswa laki-laki dan 16 orang siswa perempuan. Hasil penelitian ini menunjukkan peningkatan hasil belajar siswa dari ketuntasan belajar siswa secara klasikal pada tes awal sebesar 5,55\%. Setelah dilaksanakan siklus I, diperoleh peningkatan ketuntasan klasikal sebesar 36,11\%. Pada siklus II diperoleh peningkatan ketuntasan klasikal sebesar $86,11 \%$ atau 31 orang siswa termasuk ke dalam kategori tuntas.
\end{abstract}

Kata Kunci: Group Investigation, Hasil Belajar IPA, Pesawat Sederhana

\section{PENDAHULUAN}

Pendidikan

mengembangkan seluruh aspek

kepribadian dan kemampuan manusia baik dilihat dari aspek kognitif, apektif, dan psikomotor. Dalam pendidikan ditandai adanya interaksi edukatif agar interaksi dapat berlangsung secara efektif dan efisien dalam mencapai tujuan, maka dibutuhkan materi atau bahan yang sesuai, metode dan model yang tepat serta kualitas guru. IPA atau Sains secara harfiah dapat disebut sebagai ilmu pengetahuan tentang alam yang mempelajari peristiwa yang terjadi di alam.

Kenyataan di lapangan menunjukkan bahwa materi pelajaran IPA disajikan dengan menggunakan metode ceramah dimana guru menjelaskan teori-teori dan menjelaskan di depan kelas tanpa melibatkan siswa. Padahal materi pelajaran IPA membutuhkan suatu pengamatan, agar siswa lebih memahami materi yang diajarkan. Salah satunya adalah pesawat sederhana yang diajarkan di kelas V Sekolah Dasar. Pada materi ini diperlukan suatu model pembelajaran yang dapat mengaktifkan siswa secara langsung dalam proses pembelajaran dengan melakukan pengamatan atau praktek agar siswa dapat lebih memahami materi yang diajarkan. Peran guru bukan hanya sebagai motivator tetapi juga sebagai fasilitator dalam proses pembelajaran ini. Sudah menjadi tugas seorang guru untuk mengembangkan materi yang diajarkan dengan menggunakan model yang sesuai dengan materi yang akan diajarkan, karena pada 
dasarnya belajar siswa akan berhasil bila proses belajarnya baik yaitu melibatkan intelektual peserta didik secara optimal.

Permasalahan mengenai hasil belajar siswa dalam IPA pada materi pokok bahasan pesawat sederhana seperti yang dikemukakan di atas masih belum sesuai dengan yang diharapkan. Berdasarkan hasil observasi maka nilai siswa tergolong rendah atau di bawah standar penilaian IPA. Rendahnya hasil belajar siswa disebabkan karena guru lebih bersifat teoritis atau verbalisme dalam menyampaikan materi bahkan adapun percobaan di buku paket, guru tidak memberikan kesempatan kepada siswa untuk melakukan percobaan. Guru hanya menjelaskan dan menerangkan materinya secara teoritis. Guru lebih aktif daripada siswa hal itu ditandai dengan ketuntasan siswa dibawah nilai ketuntasan belajar yaitu 6.66. Selain itu permasalahan yang muncul adalah kurangnya media pada saat proses pembelajaran. Dalam belajar IPA atau sains sangat dibutuhkan media dalam setiap materi yang hendak diajarkan, tetapi kenyataan di lapangan kurangnya media dari sekolah bahkan guru jarang membuat sendiri media untuk proses belajar-mengajar. Dari hasil observasi dan wawancara masih ada siswa yang kurang berminat untuk belajar khususnya belajar IPA. Hal ini disebabkan karena kurangnya variasi guru dalam mengajar sehingga mereka bosan dan tidak berminat untuk belajar IPA.

Untuk melibatkan dan mengaktifkan siswa secara aktif dan langsung dalam pembelajaran IPA termasuk pesawat sederhana diperlukan suatu model pembelajaran kooperatif tipe Group Investigation dimana dalam pembelajaran atau pengetahuan tertentu ada model yang bisa ditiru. Guru dapat menjadi model dalam proses pembelajaran tetapi guru bukanlah alternatif model, artinya model dapat dirancang dengan melibatkan siswa.

Melalui model tersebut bukan berarti siswa hanya menerima materi pelajaran dari guru tetapi memancing siswa untuk ikutserta terlibat dalam proses pembelajaran. Dalam model ini guru tidak menyampaikan informasi begitu saja akan tetapi mengarahkan siswa agar dapat menemukan sendiri karena itu peran bertanya sangatlah penting. Sebab melalui pertanyaan- pertanyaan guru dapat membimbing dan mengarahkan siswa untuk menemukan pokok permasalahan dalam materi yang diajarkan .

\section{METODE PENELITIAN}

Jenis penelitian ini adalah Penelitian Tindakan Kelas yang bertujuan untuk memperbaiki proses pembelajaran untuk meningkatkan hasil belajar siswa dengan menggunakan model pembelajaran Group Investigation pada siswa kelas V SDN 104231 Sugiharjo, Batang 
Kuis T.A 2014/2015. Waktu penelitian ini adalah di semester dua T.A 2014/2015. Penelitian ini diperkirakan selama 2 bulan, terhitung dari kegiatan persiapan sampai penyusunan laporan.

Subjek penelitian tindakan kelas ini siswa Kelas V SDN 104231 Sugiharjo T.A 2014/2015 sebanyak 36 orang dengan laki-laki ada 20 orang dan perempuan sebanyak 16 orang. Objek penelitian ini adalah penerapan model pembelajaran kooperatif tipe Group Investigation pada pembelajaran IPA materi pesawat sederhana. Dalam operasional variabel penelitian ini adanya model pembelajaran Group Investigation. Model pembelajaran dengan cara siswa dibentuk kelompok oleh siswa itu sendiri dengan beranggotakan 4-6 orang, setiap kelompok bebas memilih subtopik dari keseluruhan unit materi (pokok bahasan) yang akan diajarkan, kemudian membuat atau menghasilkan laporan kelompok. Selanjutnya, setiap kelompok mempresentasikan laporannya kepada seluruh kelas, untuk berbagi dan saling tukar informasi temuan mereka.

\section{Siklus I}

Perencanaan

Kegiatan yang dilakukan pada tahap perencanaan adalah merencanakan tindakan yaitu penyusunan skenario pembelajaran.
Kegiatan yang dilakukan dalam tahap perencanaan adalah sebagai berikut :

a. Menyusun rencana pembelajaran (RPP) untuk setiap pertemuan yang memuat rencana pembelajaran dengan model pembelajaran Group Investigation .

b. Mempersiapkan materi ajar mengenai pesawat sederhana .

c. Menyiapkan media yang akan digunakan di dalam pembelajaran .

d. Mempersiapkan tes yang akan diberikan kepada siswa .

e. Menyusun instrumen penelitian yaitu lembar observasi.

\section{Pelaksanaan}

Setelah perencanaan disusun dengan baik, maka tahap selanjutnya adalah melaksanakan pembelajaran yang telah direncanakan, adapun langkah-langkah pembelajarannya sebagai berikut:

a. Pada tahap grouping guru membagi siswa ke dalam kelompok secara heterogen yaitu membagi siswa menjadi 4 kelompok. Guru menyampaikan tujuan pembelajaran .

b. Guru menjelaskan tentang materi pesawat sederhana

c. Pada tahap planning guru membimbing siswa untuk membagi topik yang berbeda pada setiap kelompok. Guru membimbing siswa dalam menyusun rencana yang akan dilakukan melalui percobaan. 
d. Pada tahap investigation guru membimbing siswa untuk berdiskusi dalam kelompok untuk mengumpulkan informasi yang diperoleh dari hasil percobaan.

e. Pada tahap organizing guru membimbing siswa dalam menulis laporan hasil percobaan, menentukan siswa yang akan menjadi penyaji laporan hasil percobaan tersebut.

f. Pada tahap presenting, guru membimbing siswa dalam penyajian laporan, guru mengatur jalannya presentasi setiap kelompok untuk mengamati tugas kelompok lain serta membimbing siswa untuk bertanya maupun menanggapi laporan hasil percobaan yang dilakukan oleh kelompok lain.

g. Pada tahap evaluating guru membimbing siswa untuk melakukan koreksi terhadap laporan masing-masing kelompok.

Pengamatan

Guru kelas mengobservasi peneliti saat melaksanakan kegiatan belajar, sedangkan teman sejawat mengobservasi aktivitas siswa selama pelajaran berlangsung.

\section{Refleksi}

Kegiatan ini dilaksanakan pada akhir pertemuan. Tahap ini mengemukakan kembali secara rinci segala sesuatu yang terjadi di kelas selama pertemuan siklus I. Jika pada tahapan siklus masih ditemukan banyak siswa yang belum mampu maka dilaksanakan siklus II, namun jika telah memenuhi tujuan yang diinginkan maka tidak perlu dilakukan tindakan pada siklus selanjutnya, dengan kata lain pembelajaran dianggap selesai.

\section{Siklus II}

Perencanaan

Pada tahap ini kegiatan yang dilakukan berupa perbaikan skenario pembelajaran yang disesuaikan hasil refleksi tindakan pada siklus 1 dengan langkah-langkah sebagai berikut:

a. Mengidentifikasi masalah-masalah yang muncul pada siklus I dan mencari alternatif pemecahan masalah

b. Menyusun rencana pelaksanaan pembelajaran (RPP).

c. Mempersiapkan alat, bahan, media, dan sumber belajar.

d. Menyusun lembar observasi

e. Dokumentasi

Pelaksanaan

Pada tahapan ini kegiatan yang dilakukan adalah merencanakan tindakan penyusunan skenario dengan menggunakan metode pembelajaran Group Investigation dengan langkahlangkah sebagai berikut:

a. Pada tahap grouping guru membagi siswa kedalam kelompok secara heterogen yaitu membagi siswa menjadi 4 kelompok .

b. Pada tahap planning guru membimbing siswa untuk 
membagi topik yang berbeda pada setiap kelompok. Guru membimbing siswa dalam menyusun rencana yang akan dilakukan melalui percobaan. Pada tahap investigation guru membimbing siswa untuk berdiskusi dalam kelompok untuk mengumpulkan informasi yang diperoleh dari hasil percobaan.

c. Pada tahap organizing guru membimbing siswa dalam menulis laporan hasil percobaan, menentukan siswa yang akan menjadi penyaji laporan hasil percobaan tersebut.

d. Pada tahap presenting guru membimbing siswa dalam penyajian laporan, guru mengatur jalannya presentasi setiap kelompok untuk mengamati tugas kelompok lain serta membimbing siswa untuk bertanya maupun menanggapi laporan hasil percobaan yang dilakukan oleh kelompok lain.

e. Pada tahap evaluating guru membimbing siswa untuk melakukan koreksi terhadap laporan masing-masing kelompok.

Pengamatan

Kegiatan pengamatan dimaksudkan untuk mengetahui bagaimana pelaksanaan tindakan dapat menghasilkan perubahan yang sesuai dengan yang diharapkan. Dalam siklus kedua ini penulis juga mengamati kinerja siswa selama pembelajaran berlangsung apakah siswa lebih aktif melaksanakan kegiatan yang dilaksanakan.

Refleksi

Kegiatan ini dilaksanakan pada akhir pertemuan. Tahap ini mengemukakan kembali secara rinci segala sesuatu yang terjadi di kelas selama pertemuan siklus I. Jika pada tahapan siklus masih ditemukan banyak siswa yang belum mampu maka dilaksanakan siklus II, namun jika telah memenuhi tujuan yang diinginkan maka tidak perlu dilakukan tindakan pada siklus selanjutnya, dengan kata lain pembelajaran dianggap selesai.

\section{HASIL DAN PEMBAHASAN}

Pembahasan ini dilakukan untuk melihat perubahan hasil belajar dari kondisi awal, siklus I hingga pada siklus II. Dengan menerapkan model pembelajaran Group Investigation, hasil belajar siswa pada pelajaran IPA materi pesawat sederhana di kelas V SDN 104231 Sugiharjo Batang Kuis, mengalami peningkatan.

Pada siklus I, dari 36 orang siswa, hanya 13 orang siswa $(36,11 \%)$ yang tuntas dalam mencapai indikator pencapaian materi, sedangkan 23 orang siswa $(63,88 \%)$ masih belum tuntas.

Dari 36 siswa yang diberikan tes awal, hanya 2 orang siswa $(5,55 \%)$ yang tuntas, sedangkan 34 orang siswa lainnya $(94,44 \%)$ masih belum tuntas dengan nilai ketuntasan minimal 66. Kemudian pada tahap 
siklus I, diketahui bahwa dari 36 orang siswa hanya terdapat 13 orang siswa $(36,11 \%)$ yang nilainya mencapai ketuntasan, sedangkan sebanyak 23 siswa lainnya $(63,88 \%)$ belum mencapai ketuntasan, dan pada siklus II mengalami peningkatan. Dari 36 siswa terdapat 31 orang siswa $(86,11 \%)$ yang mencapai ketuntasan, sedangkan 5 orang siswa $(13,88 \%)$ masih belum mencapai ketuntasan.

Berikut ini pemaparan mengenai peningkatan hasil belajar siswa dimulai dari pre-test hingga penilaian pada siklus II (post-test II).

\section{Tabel Hasil Belajar Siswa sebelum} dan Sesudah Tindakan

\begin{tabular}{|c|c|c|c|c|}
\hline \multirow{2}{*}{ No } & \multirow{2}{*}{$\begin{array}{l}\text { Pencapaian } \\
\text { Hasil Belajar }\end{array}$} & \multirow{2}{*}{$\begin{array}{l}\text { Pre } \\
\text { test }\end{array}$} & \multicolumn{2}{|c|}{ Siklus } \\
\hline & & & I & II \\
\hline 1 & $\begin{array}{l}\text { Nilai Rata- } \\
\text { rata }\end{array}$ & 44.16 & 64.16 & 81,80 \\
\hline 2 & $\begin{array}{l}\text { Jumlah Siswa } \\
\text { Tuntas }\end{array}$ & 2 & 13 & 31 \\
\hline 3 & $\begin{array}{l}\text { Persentase } \\
\text { Ketuntasan }\end{array}$ & $5.55 \%$ & $\begin{array}{l}36.11 \\
\%\end{array}$ & $\begin{array}{l}86,11 \\
\%\end{array}$ \\
\hline
\end{tabular}

\section{Grafik Persentase Peningkatan Ketuntasan Hasil Belajar Siswa}

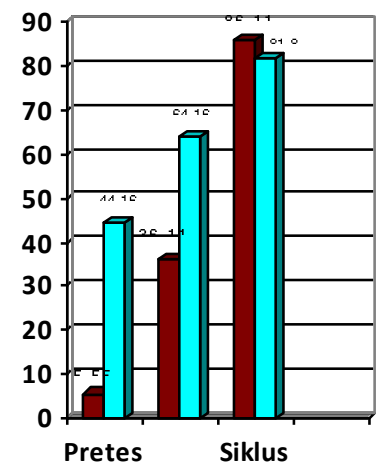

$\square$ Ketuntasan

$\square$ Rata-rata
Berdasarkan data di atas, maka hasil dari penelitian ini diperoleh bahwasannya model pembelajaran Group Investigation dapat meningkatkan hasil belajar siswa pada pelajaran IPA materi Pesawat sederhana kelas V SDN 104231 Sugiharjo, BatangKuis.

\section{SIMPULAN}

Berdasarkan hasil analisis data maka dapat diambil beberapa kesimpulan sebagai berikut :

1. Pada saat diberikan pretest diperoleh tingkat ketuntasan secara klasikal yaitu 2 orang siswa $(5.55 \%)$ dinyatakan tuntas dan 34 orang siswa ( $94.44 \%$ ) dinyatakan tidak tuntas dengan kriteria ketuntasan 66 dan pada hasil pre test nilai rata-rata diperoleh 44.16.

2. Setelah pelaksanaan siklus I menerapkan model pembelajaran kooperatif tipe group investigation diperoleh tingkat ketuntasan secara klasikal yaitu 13 orang (36.11\%) dinyatakan tuntas dan 23 orang $(63,88 \%)$ dinyatakan tidak tuntas dengan nilai rata-rata pada post test tersebut adalah 64.16.

3. Setelah pelaksanaan siklus II dengan menerapkan model pembelajaran kooperatif tipe group investigation diperoleh tingkat ketuntasan secara klasikal yaitu 31 orang $(86,11 \%)$ dengan nilai rata- rata kelas 81,80 . 
4. Penggunaan model pembelajaran kooperatif tipe group investigation dalam pelajaran IPA pada pokok bahasan pesawat sederhana dapat meningkatkan hasil belajar siswa pada proses pembelajaran di SD Negeri 104321 Sugiharjo, Batang Kuis T.A 2014/2015 .

Berdasarkan dari penelitian yang telah dilakukan, peneliti memiliki beberapa saran kepada guru agar lebih memahami konsep model pembelajaran Group Investigation sehingga guru dapat menerapkannya dalam proses pembelajaran dengan baik. Kepada guru diharapkan agar dapat menggunakan model pembelajaran yang bervariasi, salah satunya adalah model pembelajaran Group Investigation khususnya pada materi pesawat sederhana agar siswa tidak hanya belajar secara mandiri tetapi juga belajar secara kelompok sehingga siswa terbiasa bekerjasama dan berbagi ilmu pengetahuan. Kepada siswa agar tetap bisa mempertahankan car belajar yang baik serta kekompakan pada tiap kelompok belajar sehingga hasil belajarnya tetap maksimal. Hendaknya dalam hasil penelitian ini, dapat menjadi bahan perbandingan kepada peneliti lain agar dapat ditingkatkan.

\section{DAFTAR RUJUKAN}

Arikunto, S. dkk. Penelitian Tindakan Kelas. Jakarta: Bumi Aksara.
Daryanto. 2014. Pendekatan Pembelajaran Saintifik Kurikulum 2013. Yogyakarta: Gaya Media.

Dewi, R. 2010. Penelitian Tindakan Kelas. Medan: Pasca Sarjana Unimed.

Isjoni. 2009. Pembelajaran Kooperatif. Yogyakarta: Pustaka Pelajar.

Istarani. 2012. 39 Metode Pembelajaran. Medan: Iscom Medan.

Purwanto. 2011. Evaluasi Hasil Belajar. Yogyakarta: Pustaka Belajar.

Samatowa, U. 2010. Pembelajaran IPA di Sekolah Dasar. Jakarta: Indeks.

Sardiman. 2003. Motivasi Belajar Mengajar. Jakarta: Raya Grafindo Persada.

Slavin. 2005. Strategi Pembelajaran. Bandung: Kencana.

Slameto. 2010. Belajar dan FaktorFaktor yang Mempengaruhinya. Jakarta: Rhineka Cipta.

Sudjana, Nana. 2010. Penilaian Hasil Proses Belajar Mengajar. Bandung: Remaja Rosdakarya.

Uno Hamzah dan Mohamad Nurdin. 2014. Belajar dengan Pendekatan PAILKEM. Jakarta: Bumi Aksara. 